\title{
The future of Europe and the role of Eastern Europe in its past, present and future
}

\author{
Ekaterina R. Rashkova ${ }^{1}$ \\ Published online: 9 July 2020 \\ (c) European Consortium for Political Research 2020
}

\begin{abstract}
Thirty years after the fall of the Berlin Wall, and over a decade after its reunification, the European Union (EU) is experiencing increasingly more challenges toward its unity. The EU has experienced a number of crises in the early 2000s, the breakaway of one of its members in 2019, and is challenged by the Covid-19 pandemic in 2020. The latter crisis exhibits, on the one hand, the need for social coherence and unified policies, and on the other, has prompted the physical closure of borders, and divergent responses by domestic political elite. One such reaction-the adopted strengthening of power for Hungary's Prime Minister-has prompted an international outcry and re-heated the debate of the democratic backtracking of some of the new EU member-states. Analyzing the process of European Enlargement and the changing sentiments about European Integration in a number of East European countries, this symposium brings to the fore important questions about the relationship between Eastern and Western Europe. Although there is a general consensus that both the East and the West have benefited and continue to benefit from their reunion, it is nevertheless the case that the quick assimilation of liberal values has led to policies seen as threatening the liberal democracy model of the EU that we need to address in order to preserve the stability of the Union.
\end{abstract}

Keywords Accession · Eastern Europe · European Union · Illiberal democracy

The year 2019 marked the 30-year anniversary since the Fall of the Berlin wall and the reunification of Europe. It was a year of political struggle_-both externally and internally - as the European Union (EU) faced a historic break-up after the confirmation of the United Kingdom's (UK) breakaway from the EU. At the same time,

Electronic supplementary material The online version of this article (https://doi.org/10.1057/s4130 4-020-00264-z) contains supplementary material, which is available to authorized users.

Ekaterina R. Rashkova

e.rashkova@uu.nl

1 Utrecht University School of Governance, Utrecht 3511 ZC, The Netherlands 
the cohesiveness of the EU and its integral democratic values were challenged by developments, dubbed democratic backsliding, that took place in a number of East European countries. Before the EU had the chance to respond and resolve either of these challenges, it woke up to an even more dangerous crisis-one that knows no borders and one that we do not yet know how to control - the Covid-19 pandemic.

The waging Covid-19 crisis has taken a grip not only on Europe. Originating in Asia, it has spread to every corner of the world. How this new pandemic affects the world has, and will continue to have, lasting effects long after we have managed to deal with it. Projections include global economic issues and significant social changes and challenges that not only individual countries, but the world, as an intelligent global society, needs to address. Together, we will need to re-evaluate our way of living and its compatibility with the health of our society and our planet; we will have to question the constant strive for growth, which, as exemplified by the current crisis, comes at high cost; we will have to re-consider the way we eat and nourish our bodies, the way we treat our neighbors-in the common, as well as the political sense. Moreover, we will need to re-think the way we structure our societies and all their institutions, be they the 'rules that govern behavior' (North 1990), or concrete design of organizations (Scott 2003). All of these to-be-reconsidered realities bring with them political implications. How will the political elite at local, national and international level, react to the aftermath of the Covid-19 crisis, is yet to be observed. Today, however, some of the immediate implications that we see around us, remind us of a number of the ongoing internal challenges that have been appearing in the EU in the last 10 years. These include the physical closure of borders, varying policies of state-imposed rules on the conduct of society during the crisis, but also quite divergent ways in which political elites are responding to the crisisfrom the consociational style of Dutch governance to the increasingly authoritarian grip on power that we see in Hungary.

In addition to the unprecedented current dynamics, the political events of 2019Brexit, confirmed after the sweeping re-election of Boris Johnson's conservative government in December 2019, and the debate about illiberal democracy, spurred by the success of right-wing parties across Europe and intensified by developments in some of EU's new democracies from Eastern Europe (Rashkova 2019) - have posed political and economic challenges to the European Union. All of these issues and the pressures of the refugee crisis, coupled with the changing relations between the EU and Turkey, raise questions about the future of Europe. To address some of these questions, and in light of last year's 30th anniversary from the fall of communism, at the 2019 European Consortium for Political Research (ECPR) General Conference we hosted the European Political Science Annual Debate on the Future of Europe, with particular focus on the role of Eastern Europe in it. This symposium consists of the contributions to this debate.

Undoubtedly, the democratisation of Eastern Europe has had a great impact on the EU. It has significantly increased its territory and population, with Poland and Romania together, accounting for about $13 \%$ of each. This has provided an expanded market for many West European products, an opportunity for moving production facilities to the new member states, as well as an increased supply of cheaper, often seasonal, workers, who provide the much-needed extra labor in sectors like 
agriculture. At the same time, accessing East European states has also meant that these countries, which are less developed than the rest, have been net beneficiaries of the EU's structural funds and to a large extent have depended on the financial support of the richer EU states for strengthening their infrastructure (such as the network of highways). An addition to this economic side of the puzzle is perhaps the more crucial in the last few years, political side, as a number of East European states have seen an increase in illiberal practices leading to the concentration of power and growing level of Euroscepticism.

Coupled with increasing support for radical right parties in Western Europe (c.f. Front Nationale in France and the Lega Nord in Italy), these developments have brought concerns over the future direction of the EU. This particularly relates to the political leadership in the European Commission and European Parliament (EP). While the role of Eastern Europe in the future of Europe cannot be summarised single-handedly, the contributions included in this symposium give a comprehensive picture on the state of the art on European integration through the lenses of some East European states and address some of the paradoxes that quick democratisation, and the relatively fast accession to the EU, have brought. These include the still significantly under-developed and often breached minority rights, prejudice against those who are different, high levels of gender inequality and strongly entrenched gender stereotypes, all of which will take time to break. Presenting such diverse experiences to the well-settled in liberal democratic values Western Europe, which has seen significant shifts in popular will and expression itself, Eastern Europe can be said to be the catalyst to a debate on the EU governance model and its democratic legitimacy. The latter is a widely discussed topic in scholarship (Kohler-Koch and Rittberger 2007; Schmidt 2015) and in the media, yet, to date, it remains unsolved as we see by a number of cases of countries' changing political tides, more often than not, moving to increasingly conservative, even radical elite constellations.

\section{Contributions}

Introducing a number of significant moments of change, the contribution by Petr Fiala and Vit Hloušek gives a historical account of the critical junctures that East European countries have undergone since the mid-19 century. Defining critical junctures as short periods of time during which agents' choices affect the outcome of interest, they apply the concept to the contemporary state of four Central European states-Hungary, the Czech Republic, Slovakia and Poland-and discuss it vis-àvis their trajectory to and the time spent as members of the European Union. The authors argue that prior to 2004, institutional changes came as a result of the prevailing Europeanisation strategy of all governments alike. After membership was achieved, this has been gradually replaced with strategies questioning the liberal values of the European states in an attempt to define or seek the establishment of a specific character of governance, similar to the one we observe in the past years taking place in Hungary and Poland. Acknowledging these developments as a new critical juncture, the authors hope that this will not undermine but rather serve to reconsolidate the liberal democratic institutions of Central Europe. 
Similarly tackling the issue of European integration and the domestic support for the European project, in the following article Aleks Szczerbiak argues that, if one could generalise the sentiment in the entire Eastern bloc toward the EU, it would be one of change from romanticism to instrumentalism. He provides an important reminder about the overwhelmingly positive results from the pre-accession referenda in many East European countries, where, even though sceptics existed, there was little room for credibility and popularisation of their ideas and they were confined to the outskirts of the political space. The arguments for joining the EU were fourfold. Economic modernisation, geopolitical security, lack of a viable foreign policy alternative (since even where Russophilia existed as the main contender to joining the EU, this was largely manifested in opposition to North Atlantic Treaty Organisation (NATO) membership, rather than expressed Euroscepticism), and most importantly, an emotionally perceived reunification with the West, which many East Europeans regarded as being inherently part of. All of these factors, culminated in political slogans such as 'Returning to Europe'. The ensuing crises, which the EU went through - the Eurozone crisis, the Migration Crisis, the increased Euroscepticism in the European Parliament, and most recently Brexit, however changed the political discourse, and arguably preferences of many citizens and political elites in Eastern Europe. Szczerbiak argues that the Migration crisis and Brussels' reaction to it increased the popularity of Eurosceptic parties, which led to increasing questioning of the 'fit' of the distinctive East European culture, not ready to adopt multiculturalism, to that of the Europe many of these countries initially signed up to be members of.

Building on the discussion of the changing elite opinion on European integration, in the final contribution, Lenka Bustikova presents a number of paradoxes, which have emerged as a result of Eastern Europe's path to the European Union. She argues, that accession to the EU has presented the East European states with new opportunities for movement and work, but also drained their intellectual potential; it has expanded the bloc's access to Western markets, while at the same time flooding Eastern stores with inferior quality products; it has resulted in the adoption of a new set of rules - the acquis communitaire - but, at the same time, it has stimulated democratic politicians to 'weaponize institutions against their political opponents'. The main focus of the paper, however, is the debate around the expansion of minority rights and the significant illiberal institutional practices, which for a number of states in Eastern Europe have evolved into the norm. The argument that Bustikova extends is that one aspect responsible for Eastern Europe's reaction to the EU's push for multiculturalism and (ethnic, gender and other) equality, is the lack of natural growth and maturing of the society into the values of liberal, rather than simply electoral, democracy. She explains the shift toward traditional family values as an expected reaction of domestic elites who battle a significant demographic crisis, and for whom neither the robotization, nor the in-migration responses of the West, seem viable options. Thus, adopting policies that support the 'traditional family' such as boosting child care allowances, for example, have increased the popularity of parties such as Law and Justice (PiS) in Poland and Fidesz in Hungary and indirectly helped them solidify their political presence, and thus the rest of their, what some warn to be, illiberal agendas. 


\section{Conclusion}

This symposium looks at the effect of Eastern Europe on the future of Europe, reflecting upon issues of commonality and contention, 30 years after the Fall of the Berlin Wall. While generalisations are difficult to make, the contributions argue that the role of Eastern Europe in the EU is one prompting a revision, reconsideration, of the manner of adoption of the liberal democracy model. The consensus is that West European nations have had time to grow from electoral to liberal democracies, while for their East European counterparts, this growth was missing and change had to happen in a fast-forward manner, often, as a result of quickly adopted new laws meant to regulate the behavior of their societies. While the legitimacy crisis of the EU has been discussed for many years, one of its results - the strengthening of radical right and strongly outspoken Eurosceptic parties and especially their unpredicted popularity in Eastern Europe-has more recently gained significant political, as well as academic attention. The reasons for this are twofold. First, given the overwhelming support for joining the European Union, which was observed across Eastern Europe prior to 2004, did not indicate the possibility for the current political turn. Second, a troubling fact is that as one of the contributors' notes, extremism and illiberal democratic practices, came into Eastern Europe through what the author terms 'radicalization of mainstream parties'. This directly threatens not only domestic political plurality and expression of diverse opinions, but also the liberal democracy model of the European Union and its main institutions - such as the European Parliament and the European Commission.

The natural question that follows from the current debate is how will the European Union and its member-states react? This becomes especially important nowin the period of the Covid-19 pandemic-when all states are weakened, while some are using these times to increase their power vis-à-vis any political opponents and are doing this in the name of dealing with the waging health crisis. Will the difficult period through which Europe is now passing, which has forced the physical closure of borders of an entity built on the notions of freedom of movement and freedom of expression, foster strengthening and rebuilding of some, perhaps, 'lost ties' among the Union member-states, or will this unpredicted chain of events, coincidentally taking place after Brexit, and concurrent with increasing divergence with some East European countries' domestic politics, threaten the cohesiveness and the future of the Union?

\section{References}

Kohler-Koch, B. and B. Rittberger (eds.). 2007. Debating the Democratic Legitimacy of the European Union. Lanham: Rowman \& Littlefield.

North, D. 1990. Institutions, Institutional Change and Economic Performance. Cambridge: Cambridge University Press.

Rashkova, E. 2019. From'check to 'Checkmate': Analyzing the Changing Relations between Hungary and the EU. De Hofvijver 9(93). https://www.montesquieu-instituut.nl/9353000/1/j9vvj72dlowskug/ vkvfcpr7f4p3?pk_campaign=hofv-1901\&pk_kwd=vkvfcpr7f4p3. Accessed 8 June 2020. 
Schmidt, V. 2015. The Forgotten Problem of Democratic Legitimacy. In The Future of the Euro, ed. Matthias Matthijs and Mark Blythe, 90-114. Oxford: Oxford University Press.

Scott, R. W. 2003. Institutions and Organizations. Thousand Oaks: SAGE.

Publisher's Note Springer Nature remains neutral with regard to jurisdictional claims in published maps and institutional affiliations.

Ekaterina R. Rashkova is an Assistant Professor at the School of Governance at Utrecht University, the Netherlands. Her research interests lie in understanding the behaviour of political actors and the strategies they employ, given the institutional framework and the societal pressures they operate in. Currently, she is busy with better understanding substantive representation and the extent to which parties operate abroad. Her work has appeared, among others, in Comparative European Politics, European Political Science Review, International Political Science Review, Party Politics, Political Studies, Representation, West European Politics as well as in several edited book volumes. 